\title{
Inhaltsverzeichnis / Spis treści
}

\author{
Halbband / Część
}

1

Vorwort ...........................

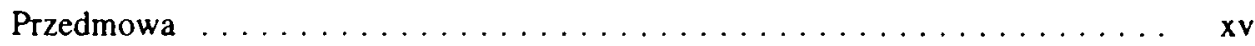

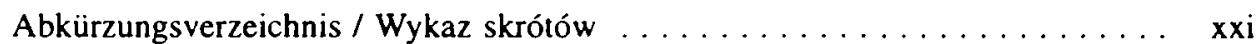

Übersichtskarte $/$ Mapa . . . . . . . . . . . . . . . . . . . xxiii

\section{Einführung / Wstẹp}

Marian Wojciechowski:

Die deutsche Minderheit in Polen $(1920-1939) \ldots \ldots \ldots \ldots \ldots$

Mniejszość niemiecka w Polsce $(1920-1939) \ldots \ldots \ldots \ldots 27$

Rudolf Jaworski:

Die polnische Grenzminderheit in Deutschland 1920-1939 . . . . . . 49

Polska mniejszość przygraniczna w latach 1920-1939 . . . . . . . . 71

Auswahlbibliographie (Darstellungen und Quellen) /

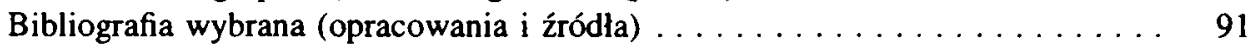

Dokumentenverzeichnis / Wykaz dokumentów . . . . . . . . . . . 105

\section{Dokumente / Dokumenty}

\section{A. Provinz Ostpreußen / Prowincja Prusy Wschodnie}

Mathias Niendorf:

Die Provinz Ostpreußen und ihre polnische Bevölkerung . . . . . . . . 159

Prowincja Prusy Wschodnie i jej ludność polska . . . . . . . . . . . . . 164

1. Provinzebene / Prowincja . . . . . . . . . . . . . . . . . . . . 169

2. Regierungsbezirk Westpreußen und Kreis Stuhm /

Rejencja Prusy Zachodnie i powiat Stuhm . . . . . . . . . 221

B. Wojewodschaft Pommerellen / Województwo pomorskie

Przemystaw Hauser:

Die deutsche Minderheit in den Wojewodschaften Posen

und Pommerellen 1919-1939

Mniejszość niemiecka w województwach poznańskim i pomorskim

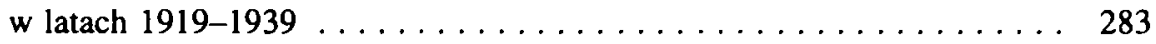

1. Wojewodschaftsebene / Województwo . . . . . . . . . . . 293

2. Landkreis / Powiat Grudziądz . . . . . . . . . . . . . . . . . . 402

3. Kreis / Powiat Sępólno Krajeńskie . . . . . . . . . . . . . . 412 
C. Provinz Grenzmark Posen-Westpreußen (Brandenburg) / Prowincja Marchia Graniczna Poznańskie-Prusy Zachodnie (Brandenburgia)

Mathias Niendorf:

Die Provinz Grenzmark Posen-Westpreußen und ihre

polnische Bevölkerung

Prowincja Marchia Graniczna Poznańskie-Prusy Zachodnie i jej

ludność polska

1. Provinzebene / Prowincja ................... 463

2. Kreis / Powiat Flatow . . . . . . . . . . . . . . . . . . . . 527

3. Kreis / Powiat Meseritz . . . . . . . . . . . . . 551

Halbband / Część

2

D. Wojewodschaft Posen / Województwo poznańskie

1. Wojewodschaftsebene / Województwo ............. 591

2. Kreis / Powiat Nowy Tomyśl . . . . . . . . . . . . . . . 728

E. Provinz Oberschlesien (Schlesien) / Prowincja Górny Ślask (Ślask)

Mathias Niendorf:

Die Provinz Oberschlesien und ihre polnische Bevölkerung . . . . . . . 811

Prowincja Górny Śląsk i jej ludność polska . . . . . . . . . . . . . . . . 817

1. Provinzebene / Prowincja . . . . . . . . . . . . . . 823

2. Landkreis / Powiat Oppeln . . . . . . . . . . . . . . . . . . 900

3. Industriegebiet / Okreg przemysłwowy . . . . . . . . . . . 927

F. Wojewodschaft Schlesien / Województwo slaskie

Przemystaw Hauser:

Die deutsche Minderheit in der Wojewodschaft Schlesien 1919-1939 . . 969

Mniejszość niemiecka w województwie śląskim w latach 1919-1939 . . 975

1. Wojewodschaftsebene / Województwo . . . . . . . . . . . 982

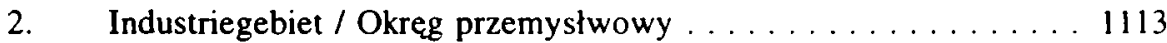

